De-globalization and De-coupling: Game Changing Consequences?

Michael Witt, Peter Ping Li, Liisa Valikangas and Arie Y. Lewin

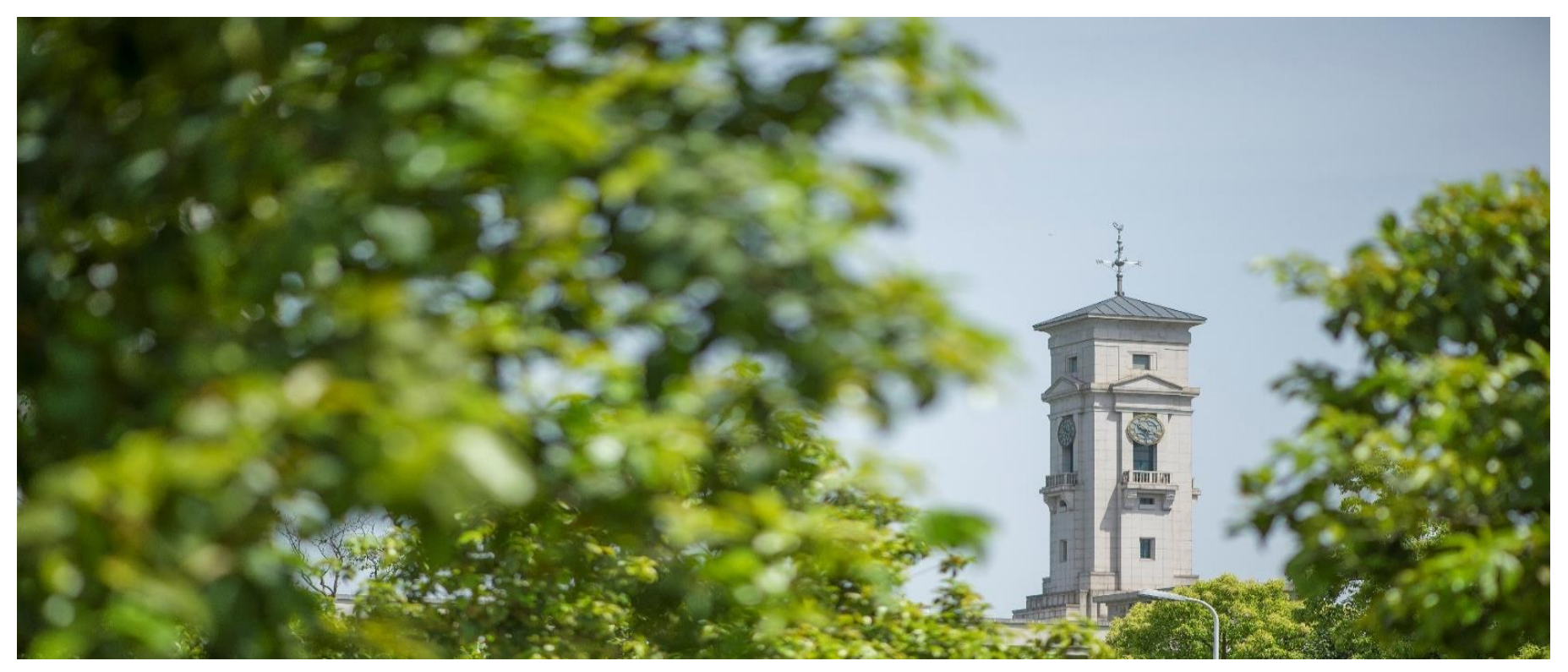


University of Nottingham Ningbo China, 199 Taikang East Road, Ningbo, 315100, China

First published 2021

This work is made available under the terms of the Creative Commons Attribution 4.0 International License:

http://creativecommons.org/licenses/by/4.0

The work is licenced to the University of Nottingham Ningbo China under the Global University Publication Licence:

https://www.nottingham.edu.cn/en/library/documents/researchsupport/global-university-publications-licence.pdf Nottingham 


\title{
De-globalization and De-coupling: Game Changing Consequences?
}

\author{
Michael Witt, Peter Ping Li, Liisa Valikangas and Arie Y. Lewin
}

(Management and Organization Review, 17:1: 6-15)

\begin{abstract}
The antecedents of de-globalization can be traced to the reemergence of China and its entry into the World Trade Organization (WTO) in 2001. In the years that followed, China experienced a massive expansion in international trade and foreign direct investment as well as strong economic development, with average growth in its gross domestic product (GDP) of more than $9 \%$ between 2001 and 2019 (World Bank, 2021). However, China has also adroitly exploited weaknesses in the world trade regime, which permitted it to avoid adhering to policies and practices on which the organization was founded and to which it was committed (Jannace \& Tiffany, 2019). The resulting imbalance in international trade and the failure of leading economists to foresee the attendant steep decline in manufacturing jobs in the US (Krugman 2018, 2019; Petricevic \& Teece, 2019) gave rise to sentiments opposing globalization, which in turn facilitated the election of President Donald Trump and accentuated his de-globalization policies. The COVID-19 pan- demic - a black swan-type event in terms of its catastrophic consequences that was surprising despite the predictions of such a health crisis - triggered a separate and independent strategic reevaluation of global value chains (GVCs) as a critical element of both international trade and foreign direct investment.
\end{abstract}

In this context, this MOR Special Forum invited commentaries on two broad questions:

1. What are the most salient contextual forces driving the trend toward de-globalization and global decoupling (e.g., geopolitical conflicts, GVCs or global supply chains, reshoring and relocation of manufacturing hubs, software development, electronic payment, platformization, and ecosystems)?

2. How can multinational enterprises (MNEs) headquartered in liberal democracies or state capitalist systems best adapt and respond to these emerging dynamics?

The first collection of commentaries features selections from the first wave of submissions, of which MOR received 27.

De-globalization has attracted growing attention across economics, political science, international business, and strategic management. It has also been of interest to scholars studying technological revolutions that affect manufacturing (e.g., three-dimensional printing, robotics, and digital transformation) as well as platformization and ecosystems that affect the reorganization of business sectors, such as hospitality, retail, fintech, and the sharing economy (e.g., Uber and the gig economy). However, it is extremely challenging to theorize about the emerging trends and directions of change or possible outcomes in these complex contexts. To provide firmer conceptual grounding for the debate, we therefore offer a coevolutionary framework in this introduction to make sense of imaginable scenarios and potential consequences.

Figure 1 provides a bird's-eye view of the coevolutionary complexity that will shape the future, especially the interdependencies of different layers of embedded- ness of the firm including international institutions (e.g., WTO), nation states, and industries and the impact 
of external factors. At the core, a coevolutionary perspec- tive is central for tracking and evaluating the complex dynamics of change (Ilinitch, D'Aveni \& Lewin, 1996; Lewin \& Volberda, 1999; Lewin, Long, \& Carroll, 1999; Volberda \& Lewin, 2003). Volberda and Lewin (2003) argued that organizational changes involve the complex, reciprocal, and iterative interaction of forces within the organization, its competitive environment, its formal and informal institutional environment, and the larger social, political, and technological environment in which firms are embedded, as summarized in Figure 1. To the extent that the enterprise or a sector experiences a radical environmental change with a material impact on its viability, adaptive processes at multiple levels will be triggered. Given growing volatility, uncertainty, complexity, and ambiguity, unpredictable and potentially far-reaching solutions and innovations will emerge from many directions and individuals (e.g., March \& Olsen, 1976). Organizations will pursue varying strategies (variation), of which only some will prove successful or acceptable (selection). As knowledge about successful adaptations spreads through an industry sector or an economy, the solutions are increasingly adopted through isomorphic processes (retention).

From a coevolutionary perspective, de-globalization and COVID-19 intro- duce potentially disruptive and far-reaching swings into the social, political, and technological environment. It is possible that organizations can accommodate these swings within the existing structures and processes or with minor tinkering. However, if these developments, whether black swanlike or not, induce major qualitative changes in international business (e.g., Witt, 2019b), international and national institutions, industries, and enterprises are likely to come under major pressure to adapt.

In the organizational context of the MNE, a wide range of structures and processes may thus be thrown into question. For instance, it seems likely that political pressures attendant to deglobalization and COVID-19 might deprive the global factory (Buckley, 2011) of part of its ability to 'fine-slice' its GVCs. What will be the key characteristics of the resultant reconfiguration? For example, what adaptations are required by the changed conditions for making value chain location choices and determining governance modes? How much and what kinds of pro- duction are relocated, nearshored, or reshored? What contingencies mediate these responses and their time horizons?

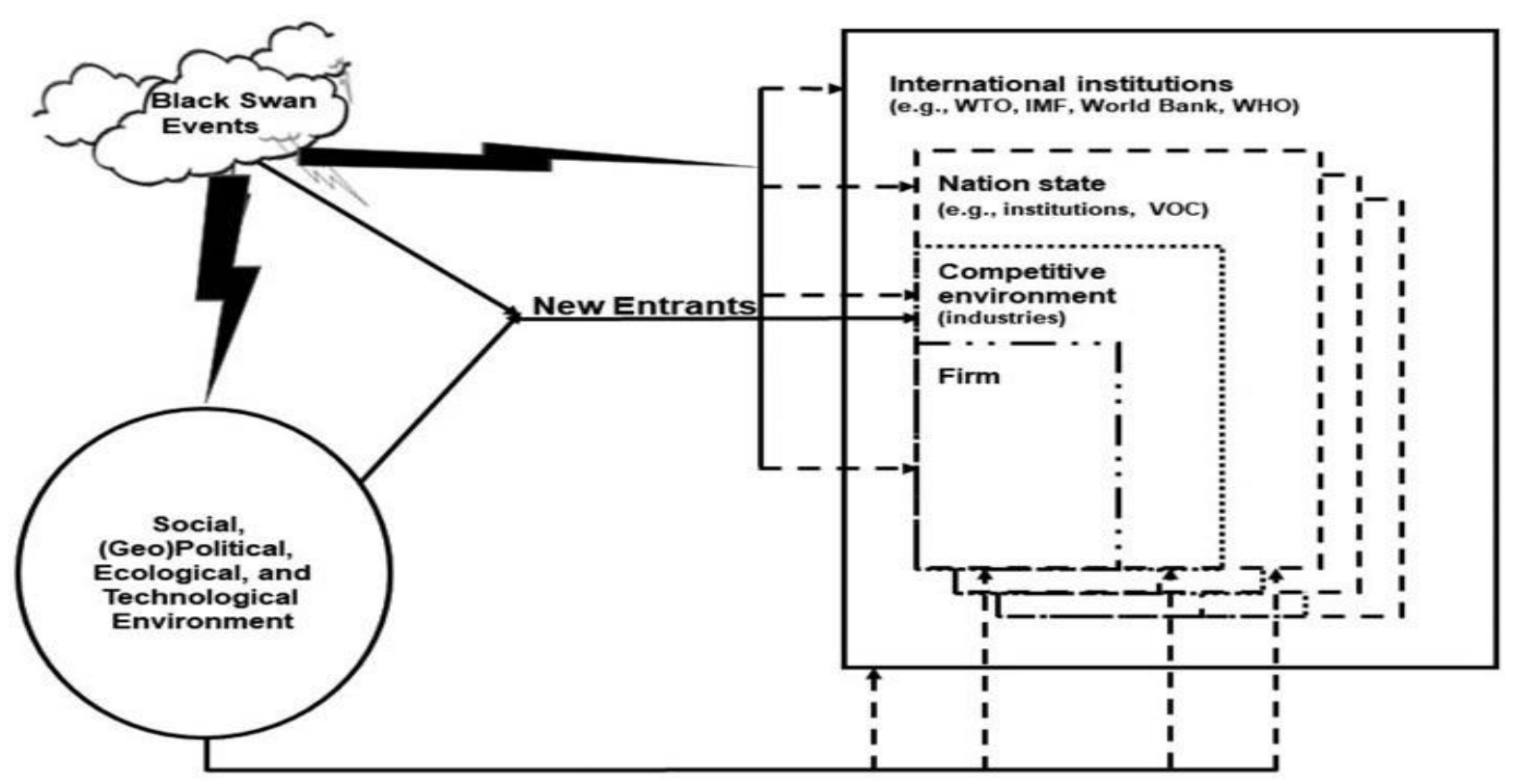


Figure 1. Co-evolution framework for theorizing consequences of de-globalization and decoupling Source: Adapted from Lewin et al., 2004

Similarly, given the distinct possibility of decoupling between China and the United States, and possibly the West more broadly, how will organizational forms and principles adapt to the growing challenge of doing business on both sides of the divide? For example, will greater decentralization and attendant localization become a new normal to avoid close association with the "other" camp? Alternatively, will higher uncertainty and concomitant increases in transaction costs lead to stronger internalization of organizational activities? To what extent are network forms of organization, such as alliances, viable risk-mitigation strategies? And is there still, or again, a role for regional headquarters in maintaining organizational cohesion in a divided world?

An important implication of the coevolutionary view is not only that organizations are likely to face adaptation pressure because of a changing macroenvironment but also that organizations in different countries will respond in distinct ways. The impact of deglobalization and COVID-19 on organizations will be mediated by national institutional systems, enabling some kinds of adaptive responses while discouraging others (see Hall \& Soskice, 2001). MOR as a journal has a long-standing interest in these national variations, especially with respect to the impact of the Chinese institutional context on organizational responses but also more widely in the context of emerging market contexts compared with the advanced industrialized countries, where most extant organizational research and theories have evolved.

This suggests a range of salient questions. For example, how does the national context codetermine and coevolve with organizational responses to de-globalization and COVID-19, whether in China or any other emerging markets? And how do these responses compare to those by advanced industrialized countries? Recent advances in research on global institutional systems (e.g., Witt, Kabbach de Castro, Amaeshi, Mahroum, Bohle, \& Saez, 2018) may be instrumental in decomposing these questions. These effects may then further interact with industry- and organizational-level factors, suggesting that research in this vein may be particularly amenable to configurational research methodologies capable of handling complex patterns of causality, such as fuzzy-set qualitative comparative analysis (Fainshmidt, Witt, Aguilera, \& Verbeke, 2020; Greckhamer, Furnari, Fiss, \& Aguilera, 2018).

The initial collection of commentaries in this MOR Special Forum contributes to the discussion on these questions from various perspectives. Specifically, in his commentary, Peter Buckley (2021) discusses the possibility of the rise of new kinds of cartel forms built around firms or industrial sectors that share GVCs or sourcing locations. Technically, this might involve building platforms similar to Airbnb or Amazon, which connect manufacturers within a sector to a customized global supply chain that can accommodate sourcing redundancies or exclude suppliers in certain countries (e.g., Kenney \& Zysman, 2020).

The commentary by Farok Contractor (2021) advances the argument that US manufacturing decline in manufacturing output relative to GDP resulted from automation, rather than globalization. Elizabeth Rose (2021), however, observes that data on US manufacturing are distorted by the outlier performance of the information and communications technology sector, because the statistics on it are included in those for manufacturing as a whole. In essence, after the statistics on the computer industry are excluded from those on US manufacturing, the decline in jobs cannot be explained by investment in automation. This 
highlights the issue of the domain and interpretation of data when discussing globalization and its impacts. Moreover, Krugman $(2018,2019)$ has recognized that the impact of China's rapid development, following its membership in the WTO in 2001, was unforeseen by many economists (including himself) in the 1990s and that the emergence of China as the world's factory contributed to the loss of jobs in US manufacturing.

The contributions by Farok Contractor and Elizabeth Rose provide a good starting point for a multidimensional discussion on the coevolution of organizational strategy embedded in its institutional context, ideally based on internationally comparative data. For example, as Contractor pointed out, US manufacturing declined $30 \%$ in terms of its proportion of GDP, from around 16\% in 1997 to around 11\% in 2018 (World Bank, 2021). However, this is not a universal pattern. Table 1 displays comparative data for five countries, each of which is the leading exponent of its respective type of capitalism (Witt et al., 2018). The decline in France is similar to that in the United States, but the drop in Japan is much smaller. Germany effectively has no change, and South Korea experienced a small increase. What differentiates these countries?

Are these countries experiencing globalization differently? As shown in Table 1, those economies that maintained higher levels of manufacturing value added also increased their proportion of exports over GDP the most, with a positive correlation of 0.70 . Of course, this does not control for other explanatory variables, but it does at least raise the possibility that globalization may be beneficial, rather than harmful (as conventional wisdom would suggest), to manufacturing in advanced industrialized economies. To the extent that this is the case, it is important to explore which factors best explain how and why countries can take advantage of globalization through exports.

Table 1. Comparative Statistics

\begin{tabular}{|l|l|l|l|l|l|l|l|}
\hline Country & $\begin{array}{l}\text { Type of } \\
\text { Capitalism }\end{array}$ & $\begin{array}{l}\text { Manufacturing } \\
\text { Value Added } \\
\text { over GDP, 2018 }\end{array}$ & $\begin{array}{l}\text { ditto, } \\
\mathbf{2 0 1 8} \\
\mathbf{1 9 9 7}\end{array}$ & $\begin{array}{l}\text { Exports } \\
\text { over GDP, } \\
\mathbf{2 0 1 8} / \mathbf{1 9 9 7}\end{array}$ & $\begin{array}{l}\text { Robot } \\
\text { Density } \\
\mathbf{2 0 1 9}\end{array}$ & $\begin{array}{l}\text { Employ- } \\
\text { ment in } \\
\text { Industry } \\
\mathbf{2 0 1 8 / 1 9 9 7}\end{array}$ & $\begin{array}{l}\text { Union } \\
\text { Density }\end{array}$ \\
\hline France & $\begin{array}{l}\text { European } \\
\text { Peripheral }\end{array}$ & $9.9 \%$ & $67 \%$ & $124 \%$ & 177 & $75 \%$ & $\begin{array}{l}8 \% \\
(2015)\end{array}$ \\
\hline Germany & $\begin{array}{l}\text { Coordinate } \\
\text { d Market }\end{array}$ & $20.1 \%$ & $99 \%$ & $187 \%$ & 346 & $77 \%$ & $\begin{array}{l}17 \% \\
(2016)\end{array}$ \\
\hline Japan & $\begin{array}{l}\text { Highly } \\
\text { Coordinate } \\
\text { d }\end{array}$ & $20.7 \%$ & $89 \%$ & $176 \%$ & 364 & $72 \%$ & $\begin{array}{l}17 \% \\
(2016)\end{array}$ \\
\hline Korea & $\begin{array}{l}\text { Advanced } \\
\text { Northeast } \\
\text { Asian }\end{array}$ & $26.6 \%$ & $108 \%$ & $147 \%$ & 855 & $80 \%$ & $\begin{array}{l}10 \% \\
(2015)\end{array}$ \\
\hline $\begin{array}{l}\text { United } \\
\text { States }\end{array}$ & $\begin{array}{l}\text { Liberal } \\
\text { Market }\end{array}$ & $11.3 \%$ & $70 \%$ & $110 \%$ & 228 & $78 \%$ & $\begin{array}{l}10 \% \\
(2016)\end{array}$ \\
\hline
\end{tabular}

Sources: Witt et al., 2018, World Bank, 2021, International Federation of Robotics, 2020, International Labour Organization, 2021 
Automation might play an important role. Table 1 shows the robotics density in manufacturing in the five economies. It is clear that manufacturing has held up much better in economies with higher levels of automation (correlation: +0.88 ). This is consistent with the argument that offshoring and automation are substitutes (Antràs, 2020). Why are some societies more open to automation than others? For example, what is it about Advanced Northeast Asian capitalism, of which South Korea is the prime exemplar, that embraces the adoption of automation? Conversely, why are Liberal Market and European Peripheral Economies - the United States and France - seemingly resistant to automation?

To the extent that labor relations play a role, as Contractor suggests, its role does not seem to be straightforward. As Table 1 indicates, the proportion of employment in manufacturing has declined to a similar degree across the five countries, and the US actually performed much better on this dimension than the conventional wisdom would suggest (lending partial support to Contractor's argument that US manufacturing has held up well in terms of employment). This measure correlates moderately (0.49) with robotic density, raising the possibility that societies that retained more employment in manufacturing might not be the ones that held back on automation but, rather, embraced it. This is consistent with the notion that automation and offshoring, usually seen as implying job losses, are substitutes. However, Table 1 also indicates that these proportions are inversely related to the density of unionization $(r=-0.42)$ In other words, societies with lower levels of organized labor seem to have preserved more manufacturing jobs. To the extent these patterns are replicated in larger samples, what mechanisms lead to this counterintuitive result?

Arjen van Witteloostuijn (2021), in his commentary, considers the dual effects of the globalization of both capital and labor. He expects the globalization of capital to reinforce and accelerate historical trends of substituting capital for labor (e.g., automation, robotics), which are the prerequisites for implementing cost-effective reshoring or nearshoring of manufacturing. The globalization of capital under this scenario has several consequences, all of them negative for labor. The overall effect of the fourth industrial revolution is to further decrease the demand for manufacturing jobs by unionized labor. Combined with the new phenomenon of working from home (WHM), companies will accelerate the shift away from employees going to work in a fixed office location. Companies will increasingly turn these WHM employees to on-demand entrepreneurs, whose long-term prospects will depend on their ability to engage in long-term learning and upgrading of their digital skills. Van Witteloostuijn also expects workers in the Anglo-Saxon countries (the UK and the US) to be affected more negatively because of the sizable availability of English-speaking talent in many countries around the world who could compete for the new WFH opportunities and who are also digitally savvy.

A central argument in Peter Williamson's (2021) commentary is that decoupling and deglobalization are ultimately irrational objectives, whose pursuit would stifle innovation, increase costs, and close off profitable opportunities. Firms consequently have an economic incentive to resist political pressure against globalization. However, economic forces are only one dimension that influences organizational strategies, as suggested by the coevolutionary framework. Firms are embedded in multiple levels that both shape and are shaped by organizational activity as well as by many other factors. To us, the role of politics looks both singularly relevant and underexplored in the International Business (IB) literature. This introduces an opportunity for advancing counterarguments on de-globalization and decoupling. 
In political science, liberalism and realism are the two major paradigms that explain globalization and de-globalization. The dominant paradigm in political science is realism and yet virtually all contributions on de-globalization and decoupling in IB have effectively ignored its analytical position and implications for company strategies. As discussed by Witt (2019a), realism sees the world in terms of a struggle for survival by sovereign nation-states in a context of global anarchy. To increase their chances of survival in the face of potential aggression from other states, countries must maximize their military and economic power relative to other states. Globalization endures where a global superpower has the ability to coerce all other states to play by its rules in the world economy. With the decline of this superpower, or hegemon, and the concomitant rise in power of a rival state, globalization gives way to de-globalization because the incumbent hegemon lacks the power to enforce the rules of the game.

In the present context, the US is a declining hegemon that led the creation of the institutional infrastructure of the world economy that is now being challenged by a rising China. The main prescription offered by realism is that, for the sake of its own sovereignty and survival, the US must do whatever it can to prevent China from gaining global hegemony. Short of a preemptive war, it can do so in three ways: (1) weaken China, (2) strengthen the US (Trump emphasized this), (3) seek and strengthen allies against China (failure to pursue this was the biggest shortcoming of Trump's foreign policy).

The main objective of decoupling is to weaken China by cutting it off from inputs that the country needs for sustaining its economic growth and military power, ideally in collaboration with other major countries. Depriving China as a whole or its leading companies of crucial inputs, such as semiconductors, is one route. Preventing Chinese nationals from gaining advanced degrees related to sensitive technologies or shutting down scientific collaboration in high-technology sectors in which the US is leading is another route. Preventing Chinese MNEs from making acquisitions in the West that could enable them to springboard technologically and scientifically is a third. Closing export markets for Chinese firms (e.g., Huawei) is a fourth.

Decoupling and attendant de-globalization imply an economic cost for the US. Under realism, however, what counts is relative power, not absolute power. As long as these measures hurt China more than the US, under realist logic, they make perfect sense. Ultimately, what is at stake is the right to self-determination and possibly even survival. The US does not want to see China emerge as its overlord. Indeed, the trade wars at least seem to affect Chinese GDP more than US GDP (The Economist, 2019). Analogously, it would be logical for US allies to accept the economic losses needed to contain China. It is true that the US has not shied from using its power, economic and military, and not always legally. But it has been more rules bound and predictable than China. It seems unlikely that Western countries would fare better with China than with the US.

Realism is ultimately about the ethical imperative of protecting your people, and their preferred way of life - a dimension entirely missing from the IB discourse on decoupling and de-globalization. In our view, exploration of the normative pressures on and ethical expectations of firms await scholarly attention. Most firms today profess that they care about acting in socially responsible ways. What does this imply in the present political context? For instance, is it ethical or socially responsible to exploit regulatory loopholes to circumvent restrictions on doing business with Chinese companies? 
Economically, the central question is what Western societies are willing to pay to preserve their way of life. Europeans forgo about six weeks of economic output each year for vacations and another two weeks for public holidays (clearly a lifestyle perk). This implies a loss of 8.3 to 12 percent of GDP annually compared with many other countries, which have two to four weeks of vacations and holidays. It is intriguing to consider whether Western societies might find it acceptable to bear a similar cost to preserve their current way of life. Some of this cost will have to be borne by companies, which could lose much or all of their business in China. Williamson argues that this will allow China to pull ahead of the West, citing the example of semiconductors. We think that this issue deserves further and deeper exploration and debate. Is decoupling really an own goal? For example, since China has made clear its intentions to lead the world in all aspects of high technology and has put the weight of the Chinese state behind this, how likely is it that other countries' high-tech firms will stand a chance against Chinese competitors in the medium to long term without state protection and support? Might decoupling save, rather than doom, Western companies?

\section{CONCLUSION}

The upsurge in anti-globalization sentiments, combined with the predictable yet still shocking COVID-19 pandemic - a black swan-type event in terms of its catastrophic consequences has triggered a strategic reevaluation of the status of globalization, including both international trade and direct foreign investment. The emergent predicament shaped by these two developments demand a fundamental rethinking of the institutional configurations that underpin international business activities. The geopolitical uncertainty that results from the clash between the current hegemon and its challenger have no direct precedent in recent history, with de-globalization and subsequent war in the 1930s and 1940s offering the closest - and most distinctly disconcerting - parallel. We believe that the coevolutionary perspective offered in this introduction may be helpful in making sense of imaginable scenarios and their potential consequences.

\section{NOTE}

Peter Ping Li acknowledges financial support from NSFC Grant 71732007.

\section{REFERENCES}

Antràs, P. 2020. De-Globalisation? Global value chains in the post-COVID-19 age. NBER Working Paper. Cambridge, MA: NBER.

Buckley, P. J. 2011. International integration and coordination in the global factory. Management International Review, 51(2): 269-283.

Buckley P. J. 2021. The return of cartels? Management and Organization Review, 17(1): https://doi.org/10.1017/mor.2020.72

Contractor F. J. 2021. A decline in US manufacturing because of globalization and China? Don't believe this fake news. Management and Organization Review, 17(1): https://doi.org/ 10.1017/mor.2020.84

The Economist. 2019, 19 October. Foggy outlook: How the twists and turns of the trade war are hurting growth. [Cited 21 December 2020]. Available from URL: https://www.economist. 
com/finance-and-economics/2019/10/17/how-the-twists-and-turns-of-the-trade-war-arehurting-growth

Fainshmidt, S., Witt, M. A., Aguilera, R. V., \& Verbeke, A. 2020. The contributions of qualitative comparative analysis (QCA) to international business research. Journal of International Business Studies, 51(4): 455-466.

Greckhamer, T., Furnari, S., Fiss, P. C., \& Aguilera, R. V. 2018. Studying configurations with qualitative comparative analysis: Best practices in strategy and organization research. Strategic Organization, 16(4): 482-495.

Hall, P. A., \& Soskice, D. 2001. An introduction to varieties of capitalism. In P.A. Hall and D. Soskice (Eds.), Varieties of Capitalism: The Institutional Foundations of Comparative Advantage: 1-68. Oxford: Oxford University Press.

Ilinitch., A.Y., D’Aveni, R.A., \& Lewin, A.Y. 1996. New organizational forms and strategies for man- aging in hypercompetitive environments. Organization Science, 7(3): 211-220.

International Federation of Robotics. 2020. Robot density in the manufacturing industry 2019. Frankfurt: International Federation of Robotics.

International Labour Organization. 2021. Statistics on union membership. Geneva: International Labour Organization.

Jannace, W., \& Tiffany, P. 2019. A new world order: The rule of law, or the law of rulers? Fordham International Law Journal, 42: 13-79.

Kenney, M., \& Zysman, J. 2020. COVID-19 and the increasing centrality and power of platforms in China, the US, and beyond. Management and Organization Review, 16(4): 747752.

Krugman, P. 2018. Globalization: What did we miss? Available from URL: https://www.gc.cuny.edu/CUNY_GC/media/LISCenter/pkrugman/PK_globalization.pdf.

Krugman, P. 2019, October 10. What economists (including me) got wrong about globalization. Bloomberg Opinion. Available from URL:

https://www.bloomberg.co/pinio/rticle/019- 10-1/nequality-globalization-and-the-misstepsof-1990s-economicsGoogleScholar/

Lewin, A.Y., Long, C. P., \& Carroll, T. N. 1999. The co-evolution of new organizational forms. Organization Science, 10(5): 535-550.

Lewin, A.Y., \& Volberda, H. W. 1999. Prolegomena on coevolution: A framework for research on strategy and new organizational forms. Organization Science, 10(5): 519-534.

Lewin, A. Y., Weigelt, C. B., \& Emery, J. B. 2004. Adaptation and selection in strategy and change: Perspectives on strategic change in organizations. In M. S. Poole and A. H. Van de Ven (eds.), Handbook of organizational change and innovation: 108-160. Oxford: Oxford University Press. 
March, J. G., \& Olsen, J. P. 1976. Ambiguity and choice in organizations. Universitesforlaget Bergen, Norway.

Petricevic, O., \& Teece, D. J. 2019. The structural reshaping of globalization: Implications for strategic sectors, profiting from innovation, and the multinational enterprise. Journal of International Business Studies, 50: 1487-1512.

Rose E. L. 2021. The decline of US manufacturing: Issues of measurement. Management and Organization Review, 17(1): https://doi.org/10.1017/mor.2020.82

Van Witteloostuijn, A. 2021. The post-corona crisis paradox: How labor will globalize to the benefit of emerging economies. Management and Organization Review, 17(1):

https://doi.org/ 10.1017/mor.2020.81

Volberda, H. W., \& Lewin, A. Y. 2003. Co-evolutionary dynamics within and between firms: From evolution to co-evolution. Journal of Management Studies, 40(8): 2111-2136.

Williamson P 2021. De-globalisation and decoupling: Post-COVID-19 myths vs realities. Management and Organization Review, 17(1): https://doi.org/10.1017/mor.2020.80

Witt, M. A. 2019a. China's challenge: Geopolitics, de-globalization, and the future of Chinese business. Management and Organization Review, 15(4): 687-704.

Witt, M. A. 2019b. De-globalization: Theories, predictions, and implications for international busi- ness research. Journal of International Business Studies, 50(7): 1053-1077.

Witt, M. A., Kabbach De Castro, L. R., Amaeshi, K., Mahroum, S., Bohle, D., \& Saez, L. 2018. Mapping the business systems of 61 major economies: A taxonomy and implications for varieties of capitalism and business systems research. Socio-Economic Review, 16(1): 538.

World Bank, 2021. World Development Indicators. Washington, DC: World Bank. 